\title{
Ingoldian fungi from the semi-arid Caatinga biome of Brazil
}

\section{Fiuza PO ${ }^{1 *}$ and Gusmão LFP1}

\begin{abstract}
${ }^{1}$ Universidade Estadual de Feira de Santana, Departamento de Ciências Biológicas, Laboratório de Micologia, Av. Transnordestina, s/n, Novo Horizonte, 44036-900, Feira de Santana, BA, Brazil. patyfiuzabio@gmail.com
\end{abstract}

Fiuza PO, Gusmão LFP 2013 - Ingoldian fungi from the semi-arid Caatinga biome of Brazil. Mycosphere 4(6), 1133-1150, Doi 10.5943/mycosphere/4/6/10

\begin{abstract}
An inventory of Ingoldian fungi from four localities of semi-arid region, Brazil (Brejo Paraibano-PB, Serra da Jibóia-BA, Chapada do Araripe and Serra de Ibiapaba-CE) is presented. Fungi were obtained from samples of foam and submerged leaves collected in water bodies. Twenty-seven taxa of Ingoldian fungi were found and of these, 22 are new records: american continent (3), Neotropics (1), South America (3), Brazil (5), Brazilian semi-arid region (7), Ceará state (2) and Paraíba state (1). Description, illustration, geographical distribution and commentary are presented for all species found.
\end{abstract}

Key words - Aquatic ecosystems - aquatic hyphomycetes - biodiversity - taxonomy - tropical

\section{Introduction}

Ingoldian fungi are aquatic hyphomycetes that exhibit sigmoid or branched conidia (Marvanová 1997). These fungi are completely dependent on the aquatic environment for reproduction since they only sporulate underwater. They are most commonly found in lotic environments with clear, clean, and well-aerated waters (Ingold 1975), but they also occur in lentic and polluted environments (Schoenlein-Crusius \& Malosso 2007). They decompose submerged substrates, making them more palatable for detritivorous invertebrates (Bärlocher 1992).

Currently, Ingoldian fungi are represented by approximately 315 species in 81 genera. Most genera are represented by only a few species and 28 genera are monotypic. Tricladium Ingold is the most diverse genus with 21 species (Campbell et al. 2009). However, the number of Ingoldian fungi species may be underestimated, considering the following three main factors: (i) the areas not yet studied, particularly tropical regions; (ii) the large variety of conidia found in foam that have not yet been described as new species (need for pure cultures); and (iii) the few researchers, at national and global levels, trained in the identification of this group of fungi.

Schoenlein-Crusius \& Grandi (2003) compiled data on the species of aquatic hyphomycetes found in South America and presented 73 taxa of Ingoldian fungi. Currently, 57 taxa have been described in Brazil (Schoenlein-Crusius \& Grandi 2003, Cavalcanti \& Milanez 2007, Cruz et al. 2007, Schoenlein-Crusius et al. 2009, Barbosa \& Gusmão 2011, Magalhães et al. 2011, Moreira \& Schoenlein-Crusius 2012, Fiuza \& Gusmão 2013). The first new species proposed in Brazil was Pyramidospora robusta Moreira \& Schoenlein-Crusius, which was found in submerged leaves of Caesalpinia echinata Lam. and Campomanesia phaea (O. Berg.) Landrum (Moreira \& SchoenleinCrusius 2012). 
Until now, eight species of Ingoldian fungi have been recorded in the Brazilian semi-arid region. Cavalcanti \& Milanez (2007) observed Dendrosporium lobatum Edgerton ex J.L. Crane in samples of soil from Pernambuco and Cruz et al. (2007) found Triscelophorus deficiens (Matsush.) Matsush. on leaves in Bahia. Barbosa \& Gusmão (2011) found Brachiosphaera tropicalis Nawawi, Ingoldiella hamata D.E. Shaw, and Scutisporus brunneus K. Ando \& Tubaki associated with submerged substrates and Fiuza \& Gusmão (2013) found Campylospora chaetocladia Ranzoni, $C$. filicladia Nawawi and C. parvula Kuzuha in foam of water bodies. Thus, studies on Ingoldian fungi in the Brazilian semi-arid region and in South America are rare.

This study aimed to conduct a taxonomic study on the Ingoldian fungi that have been found and provide descriptions, comments, and illustrations, including their worldwide geographical distribution.

\section{Materials \& Methods}

\section{Study area}

A collection expedition was conducted for each area of the study. Collections were performed in water bodies in four areas of the PPBio/Semi-arid: Brejo Paraibano from Paraíba state, Serra da Jibóia from Bahia state, Chapada do Araripe and Serra de Ibiapaba from Ceará state, where samples of foam and submerged leaves were collected for the Ingoldian fungi inventory.

\section{Sampling method}

The methods that were used were proposed by Descals (2005). Foam samples were collected and stored in $250 \mathrm{~mL}$ plastic bottles with $5 \mathrm{~mL}$ of $70 \%$ ethanol. The samples were preserved in bottles in the refrigerator. In the laboratory, the collected material was homogenized and $6 \mathrm{~mL}$ of each sample was transferred onto 30 slides. These were kept at room temperature for complete water evaporation before a drop of lactic acid was added to make semi-permanent slides. The conidia of Ingoldian fungi present in each slide were identified under an optical microscope Olympus BX-51. The identification was performed by observing the conidia and comparing them to the data found in specialized literature (Ingold 1975, Marvanová 1997, Santos-Flores \& Betancourt-López 1997). The slides were stored in the Herbário da Universidade Estadual de Feira de Santana (HUEFS). Illustrations were performed using a clear chamber coupled to an Olympus BX-51 microscope. Samples of submerged leaves were collected, stored in plastic bags, and kept in the refrigerator for the isolation of fungal cultures. In the laboratory, the samples were washed under running water (Castañeda-Ruiz 2005) and cut into $1 \mathrm{~cm}^{2}$ pieces that were placed in Petri dishes with sterile distilled water (Ingold 1975). Fragments of 0.2\% malt extract culture medium were added to the dishes. Following colonization, the fragments were transferred to a Petri dish for purification. For sporulation and subsequent identification of specimens, fragments of the pure culture isolates were submerged in a Petri dish with sterile distilled water.

\section{Results}

Twenty-seven taxa of Ingoldian fungi were found, of which 25 were observed in foam and two on submerged leaves. New records are represented by 22 taxa: American continent (3), Neotropico (1), South America (3), Brazil (5), Brazilian semi-arid region (7), Ceará state (2), Paraíba state (1).

\section{Taxonomy}

Alatospora acuminata Ingold, Trans. Br. mycol. Soc. 25(4): 384, 1942.

Fig. 1A

Conidia tetraradiate, hyaline, composed of a central axis with two branches; central axis, 3 4 septate, 30-45 × 1.5-2.8 $\mu \mathrm{m}$; curved or straight branches, 2-septate, 22.5-30 $\times 2.3 \mu \mathrm{m}$, arising after the first or second septum of base from central axis.

Geographical distribution - Cosmopolitan. 
Material examined - BRAZIL. Ceará: Missão Velha, Chapada do Araripe, river Missão Velha, in foam, 31 Mar 2011, P.O. Fiuza (HUEFS 141553).

Five species Alatospora Ingold are known: A. acuminata Ingold, A. constricta Dyko, A. crassipes Marvanová, A. flagellata (J. Gonczol) Marvanová and A. pulchella Marvanová (Marvanová 1980). The genus is characterized by exhibiting an axis with two lateral branches that may be curved or straight. Ingold (1942) collected a species in submerged leaves and isolated it in culture but it did not sporulate. However, sporulation occurred when fragments of cultures were submerged in water. Bandoni (1972) isolated a species from soil and observed that in culture the conidia did not exhibit branches. Subsequently, Gonczol \& Révay (2003) collected a species from leaves submerged in rainwater inside tree trunks. The conidia observed by these authors exhibited 0-1 branches. According to Marvanová \& Descals (1985), the number of branches is the result of sporulation conditions, such as the type of culture medium (Bandoni 1972) or the natural environment (stagnant water). Alatospora acuminata is widely distributed and is found from the cold waters of alpine streams (Gessner \& Robinson 2003) to warm tropical waters (Marvanová 1997). The species was recorded on submerged mixed leaves in São Paulo, state of Brazil (Schoenlein-Crusius \& Grandi 2003), and is a new record for the Brazilian semi-arid region.

Anguillospora longissima (Sacc. \& P. Syd.) Ingold, Trans. Br. mycol. Soc. 25(4): 402, 1942.

$\equiv$ Fusarium longissimum Sacc. \& P. Syd., Syll. fung. (Abellini) 14(2): 1128, 1899.

Figs 1 B-D

= Fusarium elongatum De Wild., Ann. Soc. Belge. Microscop. 18: 153, 1894.

Conidia filiform, curved to sigmoidal, hyaline, 7-14 septate, 105-300 $\times 3.5-6 \mu \mathrm{m}$, tapering toward both ends, $1.5-4 \mu \mathrm{m}$ wide.

Geographical distribution - Cosmopolitan.

Material examined - BRAZIL. Ceará: Missão Velha, Chapada do Araripe, river Missão Velha, in foam, 2 Aug 2011, P.O. Fiuza (HUEFS 141553); Bahia: Santa Terezinha, Serra da Jibóia, stream, in foam, 28 Feb 2012, P. O. Fiuza (HUEFS 141554); Paraíba: Alagoa Grande, Brejo Paraibano, river Pitombeira, in foam, 16 Dec 2011, P.O. Fiuza (HUEFS 141557); Ceará: Ubajara, Serra de Ibiapaba, river Minas, in foam, 22 Apr 2012, P.O. Fiuza (HUEFS 141559).

Anguillospora has sigmoid conidia and A. longissima is the type species of the genus, which is represented by 18 species (Gonczol \& Marvanová 2002). The genus is characterized by conidia with one separating cell which, in the process of secession, produces rexolytic conidia (Marvanová 1997). The remnants from the separating cell of the freed conidium rapidly become invisible (Ingold 1942). Anguillospora longissima was found by Nemec (1970) to cause strawberry root rot. The species is common in waters rich in organic matter (Nilsson 1964) and has been found in polluted subterranean waters (Krauss et al. 2003). In São Paulo, state of Brazil, it was found on submerged leaves of Ficus microcarpa L.f., Quercus robur L. and on submerged mixed leaves (Schoenlein-Crusius \& Milanez 1989, 1990, Schoenlein-Crusius 2002). This is a new record in the Brazilian semi-arid region.

Anguillospora pseudolongissima Ranzoni, Farlowia 4: 362, 1953.

Fig. 1E

Conidia filiform, sigmoidal, hyaline, 4-6 septate, 52.5-90 × 3-5 $\mu \mathrm{m}$.

Geographical distribution - Asia (Chan et al. 2000); Central America (Santos-Flores \& Betancourt-López 1997); Europe (Nilsson 1964); North America (Ranzoni 1953).

Material examined - BRAZIL. Ceará: Missão Velha, Chapada do Araripe, river Missão Velha, in foam, 29 Jul 2011, P.O. Fiuza (HUEFS 141553); Paraíba: Alagoa Grande, Brejo Paraibano, river Pitombeira, in foam, 27 Jan 2012, P.O. Fiuza (HUEFS 141557); Ceará: Ubajara, Serra de Ibiapaba, river Minas, in foam, 22 May 2012, P.O. Fiuza (HUEFS 141559).

Anguillospora pseudolongissima resembles A. longissima with regard to septation and conidium shape. Anguillospora pseudolongissima is one of the species in which rexolytic secession is not easily seen. The two species differ in conidia length: A. pseudolongissima does not excede 
$100 \mu \mathrm{m}$, whereas A. longissima has conidia up to $350 \mu \mathrm{m}$ (Ranzoni 1953, Santos-Flores \& Betancourt-López 1997). This is the first record of the species in South America.

Articulospora tetracladia Ingold, Trans. Br. mycol. Soc. 25(4): 343, 1942.

Figs $1 \mathrm{~F}-\mathrm{G}$ = Articulospora angulata Tubaki, Bull. Natn. Sci. Mus. 3: 252, 1957.

Conidia tetraradiate, hyaline, composed of a central axis with three branches; central axis, 0-4 septate, $23-37.5 \times 1.5-3 \mu \mathrm{m}$; branches with rounded ends diverging at the apex of central axis, 0-3 septate, $33-90 \times 1.5-3 \mu \mathrm{m}$.

Geographical distribution - Cosmopolitan.

Material examined - BRAZIL. Ceará: Missão Velha, Chapada do Araripe, river Missão Velha, in foam, 7 Jul 2011, P.O. Fiuza (HUEFS 141553).

Articulospora Ingold is represented by eight species, A. atra Descals, A. foliicola Matsush., A. grandis Greath., A. inflata Ingold, A. moniliformis Ranzoni, A. ozeensis Matsush., A. proliferata A. Roldán \& W.J.J. van der Merwe and A. tetracladia Ingold (Jooste et al. 1990). Articulospora tetracladia is characterized by two types of conidia: "angulata" and "tetracladia" (Nilsson 1964). The "angulata" type is produced in the air-water interface and the "tetracladia" type is produced exclusively underwater (Nilsson 1964). In the present study, only "tetracladia" type conidia were found. Articulospora tetracladia is widely distributed and occurs in waters of temperate and tropical regions, mostly in lentic environments (Nilsson 1964). Articulospora tetracladia was found in São Paulo (Schoenlein-Crusius \& Grandi 2003) and Minas Gerais (Rosa et al. 2009), states of Brazil. This is a new record in the Brazilian semi-arid region.

Brachiosphaera tropicalis Nawawi, Trans. Br. mycol. Soc. 67(2): 213, 1976.

Fig. $1 \mathrm{H}$

Conidia with globose central body, spherical to pyramidal, with four branches, sub-hyaline; central body 50-57.5 $\mu \mathrm{m}$ of diam.; cylindrical branches 3-4 septate, constricted at their base, round at the apex, $67.5-157.5 \times 7.5-10 \mu \mathrm{m}$, hyaline.

Geographical distribution - Africa (Goh 1997); Asia (Descals et al. 1976); Central America (Santos-Flores \& Betancourt-López 1997); Oceania (Goh 1997); South America (Silva \& Briedis 2011).

Material examined - BRAZIL. Ceará: Missão Velha, Chapada do Araripe, river Missão Velha, in foam, 18 Apr 2011, P.O. Fiuza (HUEFS 141553).

The genus consist of two species, B. jamaicensis (J.L. Crane \& Dumont) Nawawi and $B$. tropicalis (Descals et al. 1976). Brachiosphaera tropicalis has larger conidia $(95-180 \mu \mathrm{m})$ with fewer (4-5) branches, whereas B. jamaicensis has smaller conidia $(31-40 \mu \mathrm{m})$ with more $(10-13)$ branches (Descals et al. 1976). Brachiosphaera tropicalis conidia are similar to those of Actinospora megalospora Ingold, which are characterized by a subspherical to obpyriform shape, and the absence of constrictions at the base of the branches of the conidium (Descals et al. 1976, Marvanová 1997). The distribution of Brachiosphaera is mostly tropical, whereas Actinospora is apparently restricted to temperate regions. In South America, B. tropicalis has been recorded in Brazil, in the state of Bahia (Barbosa \& Gusmão 2011), and in Venezuela, in the state of Carabobo (Silva \& Briedis 2011). This is a new record in the state of Ceará.

Condylospora gigantea Nawawi \& Kuthub., Mycotaxon 33: 334, 1988.

Fig. 1I

Conidia cylindrical, curved, inverted L shape, hyaline, 20-25-septate; composed by a basal region longest, erect, $70.5-75 \times 2.5-3 \mu \mathrm{m}$ and an apex region smallest, slightly curved, $55.5-62.5 \times$ $2.5 \mu \mathrm{m}$, tapering toward both ends.

Geographical distribution - Africa (Chen et al. 2000); Asia (Nawawi \& Kuthubutheen 1988); Central America (Santos-Flores \& Betancourt-López 1997); Europe (Czeczuga et al. 2003).

Material examined - BRAZIL. Ceará: Ubajara, Serra de Ibiapaba, stream Gameleira, in foam, 4 Jun 2012, P.O. Fiuza (HUEFS 141558). 
Condylospora presents four species, C. flexuosa Nawawi \& Kuthub., C. gigantea Nawawi \& Kuthub., C. spumigena Nawawi and C. vietnamensis L.T.H. Yen \& K. Ando (Yen et al. 2012). Condylospora gigantea resembles $C$. spumigena in the shape of the conidia, which have a single curve. However, the most marked difference between the two species is the length of the conidium, which is twice as long in C. gigantea (Nawawi \& Kuthubutheen 1988). The distribution of the species is mainly tropical, but it has been found in temperate regions (Czeczuga et al. 2003). This is the first record of the species in South America.

\section{Condylospora sp.}

Fig. 1J

Conidia cylindrical, curved four times, hyaline, 17-24-septate; composed by a basal region, erect, 34.5-36 $\mu \mathrm{m}$ long; region between the first and second curve, 15-19.5 $\times 3 \mu \mathrm{m}$ long; region between the second and third curve, 16.5-17.5 $\times 3 \mu \mathrm{m}$; region between the third and fourth curve, $7.5 \times 3 \mu \mathrm{m}$; erect apex region, in right angle in relation to the basal region, $15 \mu \mathrm{m}$ long.

Geographical distribution - Central America (Santos-Flores et al. 1996b).

Material examined - BRAZIL. Bahia: Santa Terezinha, Serra da Jibóia, stream, in foam, 24 Oct 2011, P.O. Fiuza (HUEFS 141554).

The species of the genus are distinguished mainly by the shape and length of the conidia. These exhibit elbow-shaped curves near the median region (Nawawi \& Kuthubutheen 1988). The specimens that were observed differed from $C$. gigantea and $C$. spumigena by exhibiting an extra curve and from $C$. vietnamensis by not having a "N" or " $\mathrm{U}$ " shape. This type of conidium has been previously found by Santos-Flores et al. (1996b) in foam, water, and decomposing twigs of Andira inermis (Wright) DC, in Mayaguez, Puerto Rico. However, these authors did not identify the material beyond genus level.

Culicidospora gravida R.H. Petersen, Mycologia 55(1): 24, 1963.

Fig. $1 \mathrm{~K}$

Conidia tetraradiate, hummingbird-shaped, hyaline, composed by a central axis pyriform,

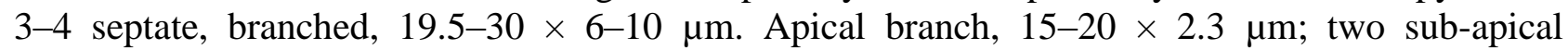
branches, $15-25 \times 2.3 \mu \mathrm{m}$; basal branch, $10-15 \times 2.3 \mu \mathrm{m}$.

Geographical distribution - Central America (Santos-Flores \& Betancourt-López 1997); Europe (Marvanová 2001); North America (Petersen 1963b); Oceania (Bärlocher et al. 2011); South America (Silva \& Briedis 2011).

Material examined - BRAZIL. Ceará: Missão Velha, Chapada do Araripe, river Missão Velha, in foam, 2 Aug 2011, P.O. Fiuza (HUEFS 141553); Paraíba: Alagoa Grande, Brejo Paraibano, river Pitombeira, in foam, 20 Dec 2011, P.O. Fiuza (HUEFS 141557).

Culicidospora R.H. Petersen has two species, C. aquatica R.H. Petersen and C. gravida (Petersen 1963b). The genus is characterized by a central axis with one branch at the apex, two in the subapical cell, and one in the basal cell. Culicidospora aquatica is larger than $C$. gravida (central axis 100-200 $\mu \mathrm{m}$ and 35-50 $\mu \mathrm{m}$ long, respectively). The conidia of the present material are smaller than those recorded for the original material (Petersen 1963b). The species has already been recorded in Venezuela (Silva \& Briedis 2011). This is the first record of the species in Brazil.

Dendrosporium lobatum Plakidas \& Edgerton ex J.L. Crane, Trans. Br. mycol. Soc. 58: 423, 1972.

Figs $1 \mathrm{~L}-\mathrm{M}$

Colonies cream-white. Mycelium immersed and superficial, composed of branched, septate, hyaline hyphae. Conidiophores mononematous, macronematous, flexuous, simple or branched, 1-2 septate, 7-20 × 2.5-3 $\mu \mathrm{m}$, smooth-walled, hyaline. Conidiogenous cells holoblastic, intercalary, sympodial, denticles, smooth-walled, hyaline. Conidia triangular, flattened, simple, hyaline, 1septate, with 2-3 lobes on each side, $10.5-15 \times 6.8-8.3 \mu \mathrm{m}$; large basal lobe; pedicellate base.

Geographical distribution - Asia (Matsushima 1980); Central America (Santos-Flores \& Betancourt-López 1997); Europe (Pascoal et al. 2005); North America (Plankidas \& Edgerton 1936, Crane 1972); Oceania (Paulus et al. 2006); South America (Castañeda-Ruiz et al. 2003). 
Material examined - BRAZIL. Paraíba: Alagoa Grande, Brejo Paraibano, river Pitombeira, in submerged decaying leaves, 20 Jan 2012, P.O. Fiuza (CCMB 571).

Dendrosporium Plakidas \& Edgerton ex J.L. Crane is represented by D. lobatum (type species) and D. candelabroides R.F. Castañeda (Castañeda-Ruiz 1986). The species is characterized by lobulated conidia in the shape of a Christmas tree. Dendrosporium lobatum was isolated from Brazilian soil by Cavalcanti \& Milanez (2007). Matsushima (1993) found the species decomposing lignicolous and folicolous submerged substrates in the river Negro, in Tambopata and in Madre de Dios, Peru. In Puerto Rico, the species occurred on submerged leaves, water, and foam (Santos-Flores \& Betancourt-López 1997). Dendrosporium lobatum was recorded by CastañedaRuiz et al. (2003) on submerged leaves in Venezuela. In this study, the specimen was isolated in a pure culture. This is a new record of the species in the state of Paraíba.

Flabellocladia tetracladia (Nawawi) Nawawi, Trans Br. mycol. Soc. 85(1): 175, 1985.

Fig. 2A $\equiv$ Flabellospora tetracladia Nawawi, Malaysian J. Sci. 2A: 55, 1973.

Conidia tetraradiate, hyaline, consisting of a cylindrical central axis, 3-septate, that origin three branches. Cylindrical axis, 30-60 × 3.5 $\mu \mathrm{m}$; branches 7-9 septate, slightly constricted at the septa, $90-110 \times 5-7 \mu \mathrm{m}$.

Geographical distribution - Asia (Nawawi 1985); Central America (Santos-Flores \& Betancourt-López 1997); South America (Silva \& Briedis 2011).

Material examined - BRAZIL. Ceará: Ubajara, Serra de Ibiapaba, river Minas, in foam, 16 Jul 2012, P.O. Fiuza (HUEFS 141559).

Flabellocladia is represented by two species, $F$. gigantea Nawawi (type species) and $F$. tetracladia (Nawawi 1985). The species differ in conidia morphology and size; $F$. gigantea has a central axis and branches that are thicker than those of $F$. tetracladia (Nawawi 1985). The two species can exhibit 3-5 branches (Nawawi 1985, Santos-Flores \& Betancourt-López 1997), but in this study, only 3 branches were observed. The morphological characteristics of the examined material are in agreement with the reviewed literature (Nawawi 1985, Santos-Flores \& BetancourtLópez 1997); however, the central axis is smaller than that observed in the literature $(60-85 \mu \mathrm{m})$. Flabellocladia tetracladia was found in foam by Silva \& Briedis $(2009,2011)$, in Venezuela. This is the first record of the species in Brazil.

Flabellospora verticillata Alas., Nova Hedwigia 15: 419, 1968.

Figs 2B-C

Conidia multiradiate, hyaline, consisting by cylindrical central axis, 0 -septate, inflated at the apex, that origin 4-7 branches; central axis, 25-25.5 × 1.5-2.5 $\mu \mathrm{m}$; branches 55.5-75 $\times 4.5-5 \mu \mathrm{m}$, constricted at the base, tapering toward end, $2.5 \mu \mathrm{m}, 5-8$ septate.

Geographical distribution - Africa (Alasoadura 1968); Asia (Sridhar \& Karamchand 2010); Central America (Santos-Flores \& Betancourt-López 1997); Oceania (Aimer \& Segedin 1985); South America (Silva \& Briedis 2011).

Material examined - BRAZIL. Ceará: Missão Velha, Chapada do Araripe, river Missão Velha, in foam, 20 Jul 2011, P.O. Fiuza (HUEFS 141553); Paraíba: Alagoa Grande, Brejo Paraibano, river Pitombeira, in foam, 19 Jan 2012, P.O. Fiuza (HUEFS 141557); Ceará: Ubajara, Serra de Ibiapaba, stream Gameleira, in foam, 5 Jun 2012, P.O. Fiuza (HUEFS 141558); Ceará: Ubajara, Serra de Ibiapaba, river das Minas, in foam, 16 Jul 2012, P.O. Fiuza (HUEFS 141559).

Flabellospora verticillata was proposed by Alasoadura (1968); it was found on submerged leaves of Phoenix dactylifera L. in Nigeria. Currently, the genus consists of five species: $F$. acuminata Descals, F. amphibia (I.P. Prince \& P.H.B. Talbot) Descals, F. crassa Alas., F. multiradiata Nawawi and F. verticillata Alas. (Descals \& Webster 1982). Conidia similar to $F$. tetracladia were observed by Ingold (1958), in foam from a stream in Uganda. However, a new species has not been proposed because the material has not been isolated in culture. Flabellospora verticillata has already been recorded in Venezuela (Silva \& Briedis 2011). This is the first record of the species in Brazil. 
Flagellospora curvula Ingold, Trans. Br. mycol. Soc. 25: 404, 1942.

Conidia filiform, sigmoidal or lunate, hyaline, 0-septate, $75-100 \times 1.5-3 \mu \mathrm{m}$.

Fig. 2D

Geographical distribution - Cosmopolitan.

Material examined - BRAZIL. Ceará: Missão Velha, Chapada do Araripe, river Missão Velha, in foam, 2 Aug 2011, P.O. Fiuza (HUEFS 141553); Bahia: Santa Terezinha, Serra da Jibóia, stream, in foam, 7 Jul 2011, P.O. Fiuza (HUEFS 141554).

Flagellospora is represented by seven species: F. curvula Ingold, F. fusarioides S.H. Iqbal, $F$. leucorhynchos Marvanová, F. minuta S.H. Iqbal \& Bhatty, F. penicillioides Ingold, $F$. saccata Marvanová \& Barl and F. stricta Sv. Nilsson (Marvanová \& Bärlocher 1989). The genus was described from $F$. curvula and is distinguished by curved sigmoid conidia. Flagellospora curvula was described on submerged leaves of Alnus glutinosa Medik and Salix sp., in a stream in Leicestershire, England (Ingold 1942). The dimensions of the examined material are smaller than usual (100-150 $\mu \mathrm{m}$ ) (Ingold 1942, Petersen 1963a). Flagellospora curvula differs from $F$. penicillioides in that it has no septum in conidia (Ingold 1944). The species was found by Webster (1977) in plant litter in the river Teign, England. In South America, Silva \& Briedis (2009) recorded $F$. curvula in Venezuela in foam. In Brazil, it was found in São Paulo on submerged mixed leaves (Schoenlein-Crusius et al. 2009), and in Minas Gerais, it was observed on submerged leaves of Protium heptaphylum Harv. and Lafoensia pacari A.St.-Hil (Rosa et al. 2009). This is a new record in the Brazilian semi-arid region.

Jaculispora submersa H.J. Huds. \& Ingold, Trans. Br. mycol. Soc. 43(3): 475, $1960 . \quad$ Figs 2E-F Conidia with central axis, subulate to navicular, hyaline, 0-septate, with 2-3 filiform branches, with a apical projection, 35-38 $\times 6 \mu \mathrm{m}$; branches inserted in the middle portion of the central axis, $12.5-15 \times 1.5 \mu \mathrm{m}$; apical projection up to $10 \mu \mathrm{m}$.

Geographical distribution - Asia (Matsushima 1987); Central America (Hudson \& Ingold 1960); Europe (Nilsson 1964); North America (Bärlocher 1987); South America (Silva \& Briedis 2009).

Material examined - BRAZIL. Ceará: Missão Velha, Chapada do Araripe, river Missão Velha, in foam, 5 Sep 2011, P.O. Fiuza (HUEFS 141553).

Jaculispora H.J. Hudson \& Ingold is a monotypic genus that was collected from submerged leaves in Jamaica (Hudson \& Ingold 1960). This was one of the first species to be described in tropical waters (Marvanová 1997). Jaculispora submersa is an anamorph of a basidiomycete, like Naiadella fluitans Marvanová \& Bandoni, which exhibits a similar morphology. Jaculispora submersa and $N$. fluitains are close in terms of conidia morphology since they exhibit an aseptate navicular axis with 2-3 branches. Naiadella fluitans has rexolytic secession, septate branches and lacks the apical projection that is visible in J. submersa. The latter has schizolytic secession and 0septate branches. Jaculispora submersa has been found in Venezuela (Silva \& Briedis 2009) and is a new record in Brazil.

Lemonniera alabamensis R.C. Sinclair \& Morgan-Jones, Mycotaxon 9(2): 469, $1979 . \quad$ Fig. 2 G

Conidia tetraradiate, hyaline, presenting a central spherical cell, 5-6.3 $\mu \mathrm{m}$ in diameter, with four branches. Branches 2-septate, divergent, without isthmus at basal cell, 30-40 × 2.5-4.5 $\mu \mathrm{m}$.

Geographical distribution - Asia (Belwal et al. 2006); Europe (Menéndez et al. 2012); North America (Sinclair \& Morgan-Jones 1979).

Material examined - BRAZIL. Ceará: Ubajara, Serra de Ibiapaba, stream Gameleira, in foam, 23 May 2012, P. O. Fiuza (HUEFS 141558).

Lemonniera De Wild. was introduced with the type species L. aquatica De Wild. The genus was revised by Descals et al. (1977), who identified six species. Subsequently, Sinclair \& MorganJones (1979) described L. alabamensis as having one central spherical cell, a characteristic that is similar to L. centrosphaera and L. pseudofloscula. Lemonniera alabamensis has smaller conidia (30-35 $\mu \mathrm{m}$ branches and a central cell of $5 \mu \mathrm{m}$ in diameter) than L. centrosphaera $(60-100 \mu \mathrm{m}$ 
branches and a central cell of 6-9 $\mu \mathrm{m}$ in diameter) (Sinclair \& Morgan-Jones 1979). The species is also close to L. pseudofloscula; however, the basal cell of the branches does not have an isthmus. This is the first record of L. alabamensis in the Neotropics.

Lemonniera pseudofloscula Dyko, Trans. Br. mycol. Soc. 69(1): 106, 1977.

Fig. $2 \mathrm{H}$

Conidia tetraradiate, hyaline, presenting a central spherical cell, 4-5 $\mu \mathrm{m}$ in diameter, with four branches. Branches 3-5-septate, divergent, with isthmus at basal cell, 31-47 × 2.5-4.5 $\mu \mathrm{m}$.

Geographical distribution - Asia (Sati et al. 2002): Central America (Santos-Flores \& Betancourt-López 1997); Europe (Fabre 1998); North America (Descals et al. 1977).

Material examined - BRAZIL. Ceará: Missão Velha, Chapada do Araripe, river Missão Velha, in foam, 19 Aug 2011, P.O. Fiuza (HUEFS 141553); Paraíba: Alagoa Grande, Brejo Paraibano, river Pitombeira, in foam, 20 Dec 2011, P.O. Fiuza (HUEFS 141557).

Lemonniera pseudofloscula was proposed in a revision of the genus by Descals et al. (1977). The species is easily distinguished from L. alabamensis and L. centrosphaera due to the presence of an isthmus in the basal cell of the branches of the conidia; it has conidia with branches up to $70 \mu \mathrm{m}$ long, whereas the branches of $L$. centrosphaera are 60-100 $\mu \mathrm{m}$ long. The conidia of $L$. pseudoflocula are initially spherical to ovoid and the branches become tetraradiate with development (Descals et al. 1977). The distribution of the species is mostly tropical and this is the first record in South America.

Lunulospora curvula Ingold, Trans. Br. mycol. Soc. 25(4): 409, 1942.

Fig. 2I

Conidia sigmoidal, lunate, hyaline, presence of submedian scar, 100-130 $\times 2.5-5 \mu \mathrm{m}$; tapering toward both ends, $1.5 \mu \mathrm{m}$ wide.

Geographical distribution - Cosmopolitan.

Material examined - BRAZIL. Ceará: Missão Velha, Chapada do Araripe, river Missão Velha, in foam, 7 Jul 2011, P.O. Fiuza (HUEFS 141553).

The genus is represented by only two species, L. curvula and L. cymbifomis K. Miura (Ingold 1975). Lunulospora curvula, was observed on submerged leaves in a stream in England and was the most abundant species during summer and autumn (Ingold 1942). The species has crescentmoon shaped or sometimes sigmoid conidia and a distinguishing scar in the submedian region because of secession (Ingold 1942). Lunulospora cymbiformis differs from L. curvula by having the median region of the conidium inflated. Singh \& Musa (1977) subjected L. curvula to terrestrial conditions and assessed the effects on growth and sporulation. In this work, L. curvula did not develop on dry leaves, only on submerged leaves, which suggests that the species is not adapted to terrestrial environments. On submerged leaves and in culture, germination, growth, and sporulation exhibited excellent results at $25^{\circ} \mathrm{C}$, suggesting a tropical distribution. Lunulospora curvula was found in São Paulo (Schoenlein-Crusius \& Milanez 1990, Schoenlein-Crusius et al. 2009) and in Minas Gerais (Rosa et al. 2009). This is the first record in the Brazilian semi-arid region.

Scutisporus brunneus K. Ando \& Tubaki, Trans. Mycol. Soc. Japan 26(2): 153, $1985 . \quad$ Fig. 2J Conidia consisting by four cells, septa cross-shaped, hyaline to subhyaline, 7.5-15 × 6-10.5 $\mu \mathrm{m}$; basal cuneiform cell, 2-7.5 $\times 2.3-4.5 \mu \mathrm{m}$, base $1.5-3 \mu \mathrm{m}$; branches projected from each cell of the body, 0-septate, filiform, hyaline, 12-18 $\mu \mathrm{m}$ long. Septa cross shaped, 3.6-7.5 $\times 4.5-6 \mu \mathrm{m}$.

Geographical distribution - Asia (Ando \& Tubaki 1985); Africa (Chen et al. 2000); Central America (Santos-Flores et al. 1996a); Oceania (Matsushima 1989); South America (Barbosa \& Gusmão 2011).

Material examined - BRAZIL. Ceará: Missão Velha, Chapada do Araripe, river Missão Velha, in foam, 20 Jul 2011, P.O. Fiuza (HUEFS 141553); Paraíba: Alagoa Grande, Brejo Paraibano, river Pitombeira, in foam, 20 Dec 2011, P.O. Fiuza (HUEFS 141557); Ceará: Ubajara, Serra de Ibiapaba, river Minas, in foam, 17 Jun 2012, P.O. Fiuza (HUEFS 141559).

Scutisporus K. Ando \& Tubaki is a monotypic genus that was proposed by Ando \& Tubaki (1985). The morphology of the conidia is the distinguishing characteristic of the species; they are 
formed by four branched cells and one cuneiform basal cell that resemble a butterfly (Ando \& Tubaki 1985). The characteristics of the examined material are in agreement with the description of the original material; however, the basal cell in this study is largest. Scutisporus brunneus was recorded in the terrestrial environment (Ando \& Tubaki 1985), but it is common in aquatic environments, either on submerged substrates or in foam (Tubaki 1965, Silva \& Briedis 2009). In Peru, S. brunneus was recorded on lignicolous substrates by Matsushima (1987); in Venezuela it was recorded in foam by Smits et al. (2007) and Silva \& Briedis (2009). In Brazil, the species was found in Bahia state on submerged leaves (Barbosa \& Gusmão 2011) and constitutes a new record in the state of Ceará.

Tetracladium breve A. Roldán, Mycol. Res. 93(4): 455, 1989.

Figs $2 \mathrm{~K}-\mathrm{M}$

Colonies yellowish to cream-white. Mycelium immersed and superficial, composed of branched, septate, hyaline hyphae. Conidiophores mononematous, macronematous, erect to flexuous, simple or branched, 0-1septate, 20-35 $\times 1.5-2.5 \mu \mathrm{m}$, smooth-walled, hyaline. Conidiogenous cells holoblastic, terminal, sympodial, denticles, smooth-walled, hyaline. Conidia tetraradiate, hyaline, consisting by central axis with three parallel and digitiform branches, and three acicular branches; central axis 16-20 × 2-3 $\mu \mathrm{m}, 1$-septate; digitiform branches 10-13.5 $\times 3.5$ $\mu \mathrm{m}, 1$-septate; acicular branches, two from straight of central axis, 20-35 $\times 2-3.5 \mu \mathrm{m}$ and one from digitiform branch, $12-16 \times 2 \mu \mathrm{m}$.

Geographical distribution - Asia (Arya \& Sati 2011); Europe (Roldán et al. 1989).

Material examined - BRAZIL. Ceará: Ubajara, Serra de Ibiapaba, river Minas, in submerged decaying leaves, 17 Aug 2012, P.O. Fiuza (CCMB 570).

Tetracladium Wild. was introduced with the type species $T$. marchalianum De Wild. Currently, the genus is comprised of eight species: T. apiense R.C. Sinclair \& Eicker, T. breve, T. furcatum Descals, T. marchalianum, T. maxilliforme (Rostr.) Ingold, T. nainitalense Sati \& P. Arya, T. palmatum A. Roldán and T. setigerum (Grove) Ingold (Sati et al. 2009). The genus is characterized by laterally flattened, tetraradiate conidia; in many species, the conidia are multiseptate with spherical to filiform sequential acicular branches (Roldán et al. 1989). The morphological characteristics and the dimensions are in agreement with the original literature, with the exception of the length of the acicular branches, which are larger in the examined material than in the type material. Roldán et al. (1989) reported that most conidia exhibited a basal extention, which was not observed in most conidia of the examined material. Tetracladium breve was isolated in culture and sporulated only when the substrate was submerged in distilled water. The species is a new record in the Americas.

Tetracladium nainitalense Sati \& P. Arya, Mycologia 101(5): 692, 2009.

Fig. $2 \mathrm{~N}-\mathrm{O}$

Conidia tetraradiate, hyaline, consisting by a central axis with two branches digitiform and a ellipsoid; central obconic axis 3-septate, 24-28 × 3-4.5 $\mu \mathrm{m}$; opposite digitiform branches, 0-1septate, appearing between the first and second septum of central axis, 7.5-15 $\times 3-4.5 \mu \mathrm{m}$; ellipsoid branches 0 -septate, appearing between the second and third septum of central axis, 4.5-6 $\times 3-4.5 \mu \mathrm{m}$.

Geographical distribution - Asia (Sati et al. 2009).

Material examined - BRAZIL. Ceará: Ubajara, Serra de Ibiapaba, stream Gameleira, in foam, 27 Jun 2012, P.O. Fiuza (HUEFS 141558).

Tetracladium nainitalense was isolated by Sati \& Arya (2009) from riparian roots of Eupatorium adenophorum Spreng. and Colocasia sp., in a stream in the Himalaya, India. The conidia of the species are very similar to those found by Aimer \& Segedin (1985) on foam and it is identified as Tetracladium sp. The conidia of $T$. nainitalense are distinguished by not exhibiting acicular branches (Sati et. al. 2009). This is the second record of the species in the world and a new record in the Americas. 
Conidia tetraradiate, hyaline, consisting by a central curved to sigmoid axis, cylindrical, $46.5-69 \times 2.3 \mu \mathrm{m}, 7-8$ septate, acicular apex and truncated base, two lateral branches in the same plane; constricted branches in the inserting of central axis; the first, 4-5septate, is inserted after to third septum from the base, $30-45 \times 2.3 \mu \mathrm{m}$; the second 3-4 septate, is inserted after to fourth septum, $22.5-34.5 \times 2.3 \mu \mathrm{m}$.

Geographical distribution - Europe (Marvanová 1984).

Material examined - BRAZIL. Ceará: Ubajara, Serra de Ibiapaba, river Minas, in foam, 18 Jun 2012, P.O. Fiuza (HUEFS 141559).

Tricladium was introduced by Ingold (1942) with T. splendens Ingold (type species) and $T$. angulatum Ingold. Currently, the genus is composed of 21 species (Campbell et al. 2009) and is one of the largest amongst Ingoldian fungi. Tricladium fallax differs from all other species by having curved to sigmoid conidia, with branches markedly constricted at the base and with acicular extremities (Marvanová 1984). The species was observed in foam by Marvanová $(1984,2001)$ and Descals et al. (1995) in streams in Slovakia, the Czech Republic and Spain, respectively. Tricladium fallax is a new record in the Americas.

Trinacrium incurvum Matsush., Matsush. Mycol. Mem. 7: 70, 1993.

Fig. 2Q

Conidia T-shaped, hyaline, consisting by central axis with two branches that bend towards the axis; central axis, slightly club-shaped, 3-4 septate, 32-36 $\times 4.5-6 \mu \mathrm{m}$; curved branches, 3-4 septate, $18.5-20 \times 4.5 \mu \mathrm{m}$.

Geographical distribution - Asia (Sati et al. 2002); Central America (Santos-Flores \& Betancourt-López 1997); South America (Matsushima 1993).

Material examined - BRAZIL. Ceará: Missão Velha, Chapada do Araripe, river Missão Velha, in foam, 31 Mar 2011, P.O. Fiuza (HUEFS 141553).

Trinacrium incurvum was described from decomposing submerged twigs from the river Monanti in Peru (Matsushima 1993). It was subsequently isolated from submerged leaves in Puerto Rico (Santos-Flores \& Betancourt-López 1997). The current specimen differs from the original description in that it has larger conidia. However, its dimensions are in agreement with those described by Sati et al. (2002) in material collected in Asia. Trinacrium incurvum has a tropical distribution. This is a new record in Brazil.

Triscelophorus acuminatus Nawawi, Trans. Br. mycol. Soc. 64(2): 346, 1975.

Fig. 2R

Conidia tetraradiate, hyaline, central axis with three branches inserted in basal cell; central axis, cylindrical, 3-8 septate, tapering at the apex, the septa are not constricted, $24-85 \times 2-3 \mu \mathrm{m}$; cylindrical branches 3-4 septate, $37.5-75 \times 2-3 \mu \mathrm{m}$. The basal cell by axis presents truncated base. Has not abrupt change in wide of basal cell from middle axis towards the apex, $4.5-6 \times 7.5-9 \mu \mathrm{m}$.

Geographical distribution - Cosmopolitan.

Material examined - BRAZIL, Ceará, Missão Velha, Chapada do Araripe, river Missão Velha, in foam, 11 Jul 2011, P.O. Fiuza (HUEFS 141553); Bahia, Santa Terezinha, Serra da Jibóia, stream, in foam, 7 Jul 2012, P.O. Fiuza (HUEFS 141554); Paraíba: Alagoa Grande, Brejo Paraibano, river Pitombeira, in foam, 9 Dec 2011, P.O. Fiuza (HUEFS 141557); Ceará, Ubajara, Serra de Ibiapaba, stream Gameleira, in foam, 27 Jul 2012, P.O. Fiuza (HUEFS 141558); Ceará, Ubajara, Serra de Ibiapaba, river das Minas, in foam, 13 Jul 2012, P.O. Fiuza (HUEFS 141559).

The genus contains eight species: T. acuminatus, T. curviramifer Matsush., T. deficiens (Matsush.) Matsush., T. konajensis K.R. Sridhar \& Kaver., T. magnificus R.H. Petersen, T. monosporus Ingold, T. ponapensis Matsush. and T. septatus Wolfe (Matsushima 1993, Marvanová 1997, Santos-Flores \& Betancourt-López 1997). The dimensions of the examined material are in agreement with the original literature (Nawawi 1975), with the exception that the central axis and the branches are narrower. Triscelophorus acuminatus has a similar morphology to that of $T$. monosporus and T. magnificus. Triscelophorus monosporus is distinguished by the absence of septa and T. magnificus is characterized by the length of the branches (up to $200 \mu \mathrm{m}$ ) and constricted 
septa. In Brazil, five species have been found: T. monosporus and T. magnificus on submerged leaves of Quercus robur L. (Schoenlein-Crusius et al. 1990), in São Paulo, T. deficiens (Matsush.) Matsush. on dead leaves from the semi-deciduous forest of Bahia (Cruz et al. 2007), T. curviramifer on dead leaves from the Atlantic Forest in south of Bahia (Magalhães et al. 2011) and T. acuminatus. This was recorded in Venezuela in foam (Silva \& Briedis 2009, 2011) and in the Brazil, state of São Paulo, on submerged leaves (Moreira \& Schoenlein-Crusius 2012). The species is a new record in the Brazilian semi-arid region.

Trisulcosporium acerinum H.J. Huds. \& B. Sutton, Trans. Br. mycol, Soc. 47(2): 200, 1964.

Fig. 2S

Conidia triradiate, hyaline, consisting by a central axis with two branches inserted in basal cell; central cylindrical axis, constricted at the septa, 4-6 septate, 37.5-55 × 3-4.5 $\mu \mathrm{m}$; lateral cylindrical branches, constricted at the septa, 1-2 septate, $18-22.5 \times 3 \mu \mathrm{m}$.

Geographical distribution - Cosmopolitan.

Material examined - BRAZIL. Paraíba, Alagoa Grande, Brejo Paraibano, river Pitombeira, in foam, 16 Dec 2011, P.O. Fiuza (HUEFS 141557); Ceará, Ubajara, Serra de Ibiapaba, stream Gameleira, in foam, 15 Jul 2012, P.O. Fiuza (HUEFS 141558).

Trisulcosporium H.J. Huds. \& B. Sutton is a monotypic genus represented by T. acerinum (Hudson \& Sutton 1964). In the original description, the material exhibits 2-3 branches; in the present study, the conidia that were found have 2 branches. Prior to its description, conidia resembling those of T. acerinum were collected in foam and illustrated by Ingold (1958). In Puerto Rico, T. acerinum was observed on foam, submerged leaves, and water (Santos-Flores \& Betancourt-López 1994, 1997). The species was recorded in São Paulo, state of Brazil, on submerged leaves of Alchornea triplinervia (Spreng.). M. Arg. and Ficus microcarpa L.F. (Schoenlein-Crusius et al. 1992), and is a new record in the Brazilian semi-arid region.

\section{List with other taxa found}

All species of Campylospora was recorded in Fiuza \& Gusmão (2013), through descriptions, comments, illustrations and geographical distribution.

Campylospora chaetocladia Ranzoni, Farlowia 4: 373, 1953.

Material examined - BRAZIL, Ceará, Missão Velha, Chapada do Araripe, river Missão Velha, in foam, 2 Aug 2011, P.O. Fiuza (HUEFS 141553); Paraíba, Alagoa Grande, Brejo Paraibano, river Pitombeira, in foam, 16 Dec 2011, P.O. Fiuza (HUEFS 141557); Ceará, Ubajara, Serra de Ibiapaba, stream Gameleira, in foam, 15 Jun 2012, P.O. Fiuza (HUEFS 141558).

Campylospora filicladia Nawawi, Trans. Br. mycol. Soc. 63(3): 604, 1974.

Material examined - BRAZIL, Ceará, Ubajara, Serra de Ibiapaba, river Minas, in foam, 18 Jul 2012, P.O. Fiuza (HUEFS 141559).

Campylospora parvula Kuzuha, J. Jap. Bot. 48(7): 220, 1973.

Material examined - BRAZIL, Ceará, Ubajara, Serra de Ibiapaba, stream Gameleira, in foam, 27 Jul 2012, P.O. Fiuza (HUEFS 141558).

\section{Campylospora sp.}

Material examined - BRAZIL, Ceará, Ubajara, Serra de Ibiapaba, river Minas, in foam, 28 May 2012, P.O. Fiuza (HUEFS 141559). 


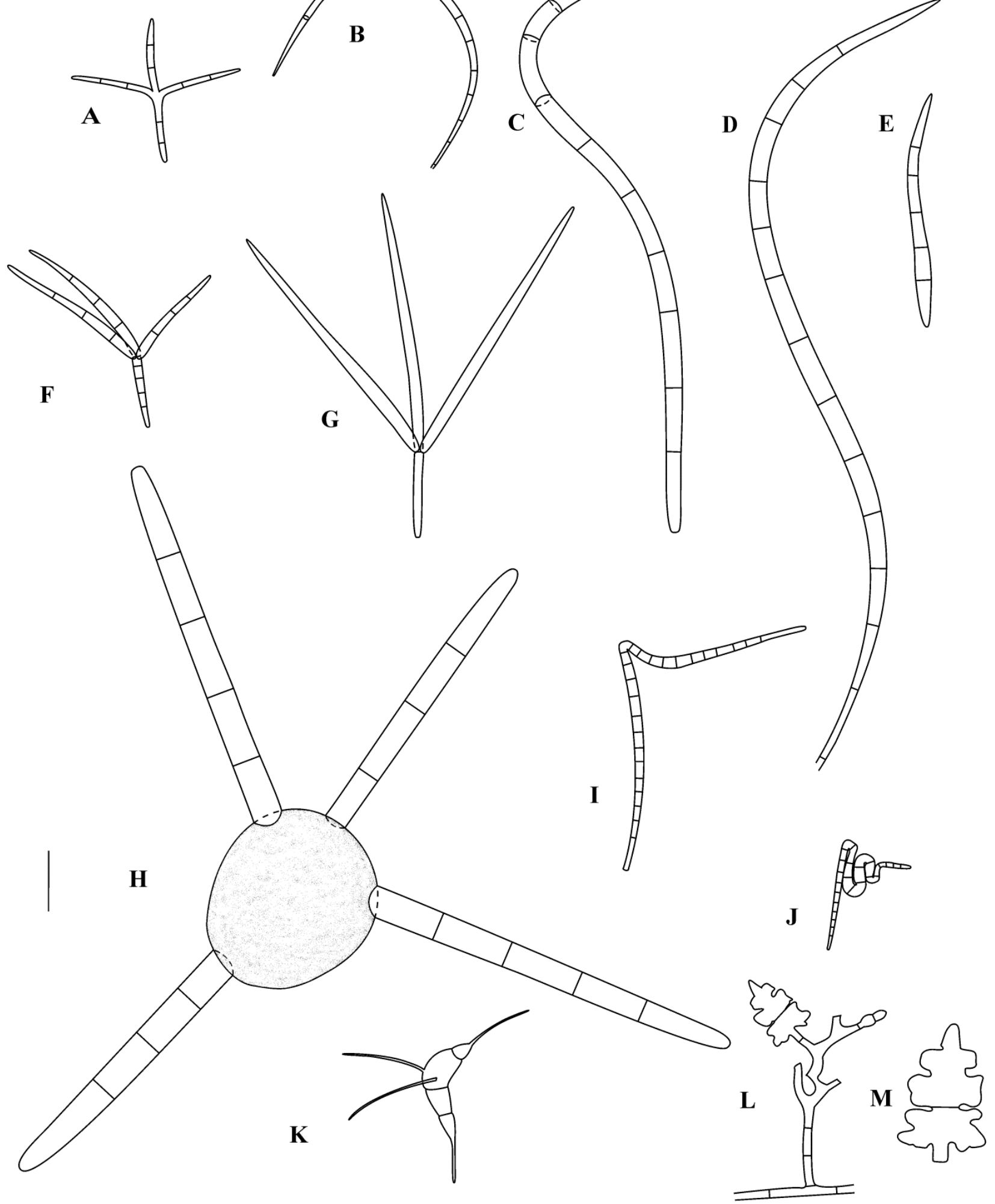

Fig. 1 - A Alatospora acuminata; B-D Anguillospora longissima; E A. pseudolongissima; F-G Articulospora tetracladia; H Brachiosphaera tropicalis; I Condylospora gigantea; J Condylospora sp.; K Culicidospora gravida; L-M Dendrosporium lobatum. (Bar: A-K = $20 \mu \mathrm{m}, \mathrm{L}-\mathrm{M}=5 \mu \mathrm{m}$ ). 


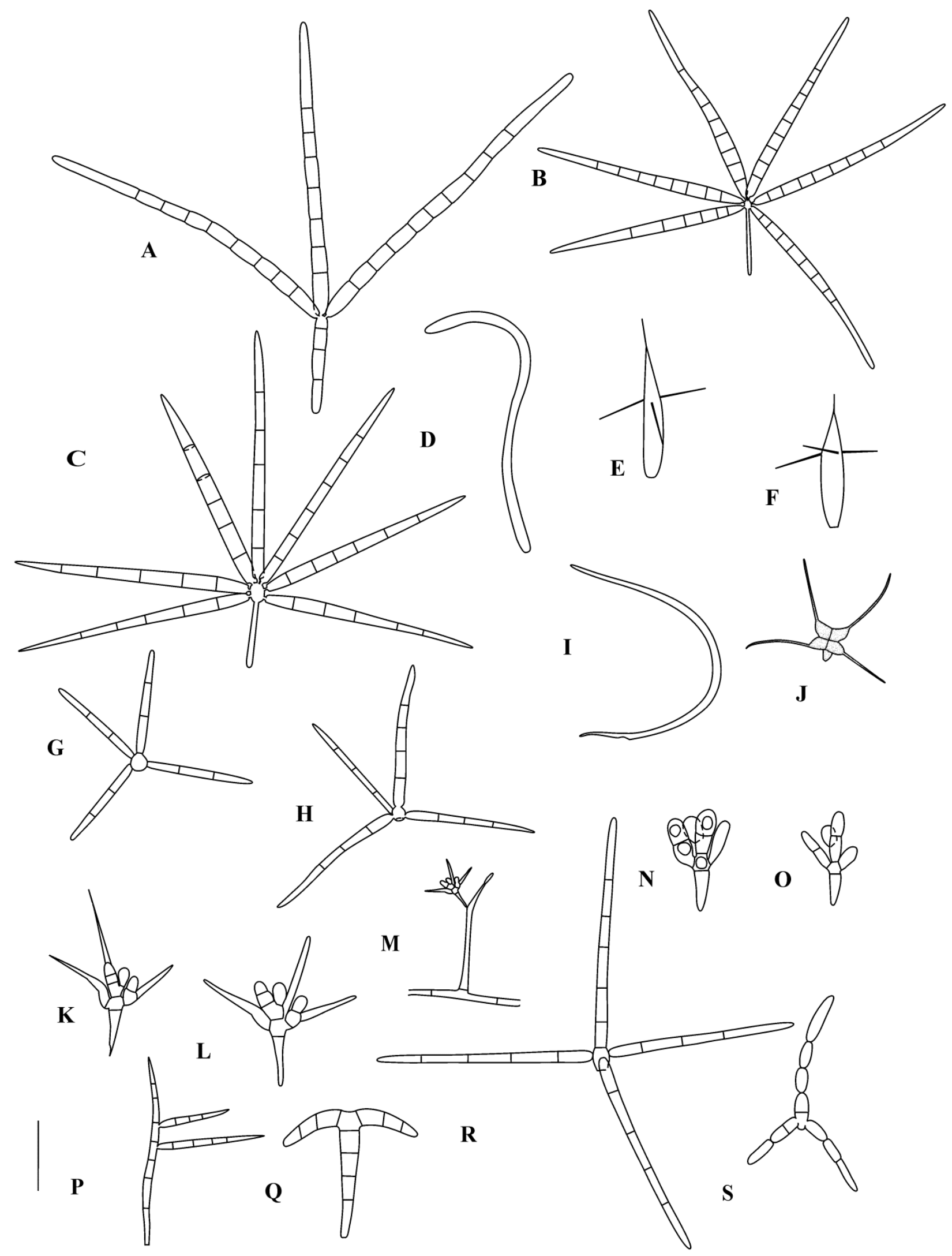

Fig. 2 - A Flabellocladia tetracladia; B-C Flabellospora verticillata; D Flagellospora curvula; EF Jaculispora submersa; G Lemonniera alabamensis; H L. pseudofloscula; I Lunulospora curvula; J Scutisporus brunneus; K-M Tetracladium breve; N-O T. nainitalense; P Tricladium fallax; Q Trinacrium incurvum; R Triscelophorus acuminatus; S Trisulcosporium acerinum. $(\mathrm{Bar}=20 \mu \mathrm{m})$. 


\section{Acknowledgements}

The authors wish to thank Ludmila Marvanová, Iracema Schoenlein-Crusius and Flavia Barbosa, for literatures; and "Programa de Pesquisa em Biodiversidade do Semiárido" (proc. 558317/2009-0) for financial support in collecting. PO Fiuza thanks "Programa de Pós-graduação em Botânica (UEFS)" and "Coordenação de Aperfeiçoamento de Pessoal de Nível Superior (CAPES)" for granting scholarships and LFP Gusmão extended thanks to CNPq (proc. 303924/2008-0).

\section{References}

Aimer RD, Segedin BP. 1985 - Some aquatic hyphomycetes from New Zealand streams. New Zealand Journal of Botany 23, 273-299.

Alasoadura SO. 1968 - Flabellospora verticillata, a new species of aquatic hyphomycete from Nigeria. Nova Hedwigia 15, 419-421.

Ando K, Tubaki K. 1985 - Three new Hyphomycetes from Japan: Anthopsis microspora, Scutisporus brunneus and Titaeella capnophila. Transactions of the Mycological Society of Japan 26, 151-160.

Arya P, Sati SC. 2011 - Evaluation of endophytic aquatic hyphomycetes for their antagonistic activity against pathogenic bacteria. International Research Journal of Microbiology 2(9), 343-347.

Bandoni RJ. 1972 - Terrestrial occurrence of some aquatic hyphomycetes. Canadian Journal of Botany 50, 2283-2288.

Barbosa FR, Gusmão LFP. 2011 - Conidial fungi from semi-arid Caatinga Biome of Brazil. Rare freshwater hyphomycetes and other new records. Mycosphere 2(4), 475-485.

Bärlocher F. 1987 - Aquatic hyphomycetes spora in 10 streams of New Brunswick and Nova Scotia. Canadian Journal of Botany 65, 76-79.

Bärlocher F. 1992 - Research on aquatic hyphomycetes: historical background and overview. In: The ecology of aquatic hyphomycetes: Ecological Studies. (ed. Bärlocher F.). SpringerVerlag, Berlin 1-15.

Bärlocher F, Stewart M, Ryder DS. 2011 - Analyzing aquatic fungal communities in Australia: impacts of sample incubation and geographic distance of streams. Czech Scientific Society for Mycology 63(2), 113-132.

Belwal M, Pargaien N, Bisht S. 2006 - Species composition of waterborne conidial fungi in two altitudinally different streams of Kumaun Himalaya. In: Recent Mycological Researches. (ed. Sati SC.) I. K. International Publishing House, New Delhi 194-202.

Campbell J, Marvanová L, Gulis V. 2009 - Evolutionary relationships between aquatic anamorphs and teleomorphs: Tricladium and Varicosporium. Mycological Research 113, 1322-1334.

Cavalcanti MS, Milanez AI. 2007 - Hyphomycetes isolados da água e do solo da Reserva Florestal de Dois Irmãos, Recife, PE, Brasil. Acta Botanica Brasilica 21(4), 857-862.

Castañeda-Ruiz RF. 1986 - Fungi cubenses. Revista Del Jardín Botánico Nacional Universidad de La Habana, Havana.

Castañeda-Ruiz RF. 2005 - Metodologia en el estudio de los hongos anamorfos; V Congresso Latino Americano de Micologia. University of Brasília, Brasília.

Castañeda-Ruiz RF, Iturriaga T, Minter DW, Saikawa M, Vidal G, Velazquez-Noa S. 2003 Microfungi from Venezuela, A new species of Brachydesmiella, a new combination, and new records. Mycotaxon 85, 211-229.

Chan SY, Goh TK, Hyde KD. 2000 - Ingoldian fungi in Hong Kong. In: Aquatic Mycology across the Millennium (eds Hyde KD, Ho WH, Pointing SB.). Fungal Diversity, Hong Kong 89107.

Chen JS, Feng MG, Fomelack TS. 2000 - Aquatic and aero-aquatic hyphomycetes occurred in central Cameroon, Western Africa. Pakistan Journal of Biological Sciences 3(11), 18471848 . 
Crane JL. 1972 - Illinois Fungi. III. Dendrosporium lobatum and Sporidesmium taxodii sp. nov. Transactions of the British Mycological Society 58(3), 423-426.

Cruz ACR, Marques MFO, Gusmão LFP. 2007 - Fungos anamórficos (Hyphomycetes) da Chapada Diamantina: novos registros para o Estado da Bahia e Brasil. Acta Botanica Brasilica 21(4), $847-855$.

Czeczuga B, Kiziewicz B, Mazalska B. 2003 - Further studies on aquatic fungi in the River Biebrza within Biebrza National Park. Polish Journal of Environmental Studies 12(5), 531543.

Descals E. 2005 - Techniques for handling Ingoldian Fungi. In: Methods to Study Litter Decomposition (eds Graça MAS, Barlocher F, Gessner MO). Springer, Dordrecht 129-141.

Descals E, Webster J. 1982 - Taxonomic studies on aquatic hyphomycetes III. Some new species and a new combination. Transactions of the British Mycological Society 78(3), 405-437.

Descals E, Nawawi A, Webster J. 1976 - Developmental studies in Actinospora and similar aquatic hyphomycetes. Transactions of the British Mycological Society 67(2), 207-222.

Descals E, Webster J, Dyko BS. 1977 - Taxonomic studies on aquatic aquatic hyphomycetes. I Lemonniera De Wildeman. Transactions of the British Mycological Society 69(1), 89-109.

Descals E, Peláez F, López Llorca LV. 1995 - Fungal spora of stream foam from central Spain I. Conidia identifiable to species. Nova Hedwigia 60(3-4), 533-550.

Fabre E. 1998 - Aquatic hyphomycetes in three rivers of southwestern France. II. Spatial and temporal differences between species. Canadian Journal of Botany 76, 107-114.

Fiuza PO, Gusmão LFP. 2013 - Ingoldian fungi from semiarid Caatinga biome of Brazil. The genus Campylospora. Mycosphere 4(3), 559-565.

Gessner MO, Robinson MCT. 2003 - Aquatic hyphomycetes in alpine streams. In: Ecology of Glacial Foodplain (eds Ward JV, Uehlinger U.). Kluwer Academic Publishers, Dordrecht 123-137.

Goh TK. 1997 - Tropical freshwater hyphomycetes. In: Biodiversity of Tropical Microfungi (ed. Hyde KD. ). Hong Kong University Press, Hong Kong 189-227.

Gonczol J, Marvanová L. 2002 - Anguillospora mediocris sp. nov. from streams in Hungary. Czech Scientific Society for Mycology 53, 309-317.

Gonczol J, Révay Á. 2003 - Treehole fungal communities: aquatic, aero-aquatic and dematiaceous hyphomycetes. Fungal Diversity 12, 19-34.

Hudson HJ, Ingold CT. 1960 - Aquatic hyphomycetes from Jamaica. Transactions of the British Mycological Society 43(3), 469-478.

Hudson HJ, Sutton BC. 1964 - Trisulcosporium and Tetranacrium, two new genera of fungi imperfecti. Transactions of the British Mycological Society 47(2), 197-203.

Ingold CT. 1942 - Aquatic hyphomycetes of decaying alder leaves. Transactions of the British Mycological Society 25, 339-417.

Ingold CT. 1944 - Some new aquatic hyphomycetes. Transactions of the British Mycological Society 25, 339-417.

Ingold CT. 1958 - Aquatic hyphomycetes from Uganda and Rhodesia. Transactions of the British Mycological Society 41, 109-114.

Ingold CT. 1975 - Conidia in the foam of two English streams. Transactions of the British Mycological Society 65(3), 522-527.

Ingold CT. 1975 - An illustrated guide to aquatic and waterborne hyphomycetes (fungi imperfect). Freshwater Biological Association Scientific Publication, Cumbria.

Jooste WJ, Roldan A, Van Der Merwe WJJ, Honrubia M. 1990 - Articulospora proliferata sp. nov., an aquatic hyphomycete from South Africa and Spain. Mycological Research 94(7), 947-951.

Krauss G, Sridhar KR, Jung K, Wennrich J, Ehrman J, Bärlocher F. 2003 - Aquatic hyphomycetes in polluted groundwater habitats of central Germany. Microbial Ecology 45, 329-339.

Magalhães DMA, Luz EDMN, Magalhães AF, Santos Filho LP, Loguercio LL, Bezerra JL. 2011 Riqueza de fungos anamorfos na serapilheira de Manilkara maxima, Parinari alvimii e 
Harleyodendron unifoliolatum na Mata Atlântica do Sul da Bahia. Acta Botanica Brasilica 25, 899-907.

Marvanová L. 1980 - New or noteworthy aquatic hyphomycetes. Clavatospora, Heliscella, Nawawia e Heliscina. Transactions of the British Mycological Society 75(2), 221-231.

Marvanová L. 1984 - Two new Tricladium species from mountain streams. Mycotaxon 19, 93100.

Marvanová L. 1997 - Freshwater hyphomycetes: a survey with remarks on tropical taxa. In: Tropical Mycology (eds Janardhanan KK, Rajendran C, Natarajan K, Hawksworth DL.). Science Publishers, Enfield 169-226.

Marvanová L. 2001 - Streamborne fungal spora in running waters of the bohemian forest. Silva Grabeta 7, 147-154.

Marvanová L, Bärlocher F. 1989 - Hyphomycetes from Canadian streams. Three new taxa. Mycotaxon 35(1), 85-99.

Marvanová L, Descals E. 1985 - New and critical taxa of aquatic hyphomycetes. Botanical Journal of the Linnean Society 91, 1-23.

Matsushima T. 1975 - Icones Microfungorum a Matsushima Lectorum. Published by the author, Kobe.

Matsushima T. 1980 - Saprophytic microfungi from Taiwan - Part 1 Hyphomycetes. Published by the author, Kobe.

Matsushima T. 1987 - Matsushima Mycological Memoirs No 5. Published by the author, Kobe.

Matsushima T. 1989 - Matsushima Mycological Memoirs $N^{\circ}$ 6. Published by the author, Kobe.

Matsushima T. 1993 - Matsushima Mycological Memoirs No 7. Published by the author, Kobe.

Menéndez M, Descals E, Riera T, Moya O. 2012 - Effect of small reservoirs on leaf litter decomposition in Mediterranean headwater streams. Hydrobiologia 691,135-146.

Moreira CG, Schoenlein-Crusius IH. 2012 - Nova espécie e novos registros para o Brasil de hifomicetos em folheto submerso coletados no Parque Municipal Alfredo Volpi, São Paulo, SP, Brasil. Hoehnea 39(4), 521-527.

Nawawi A. 1975 - Triscelophorus acuminatus sp. nov. Transactions of the British Mycological Society 64(2), 345-348.

Nawawi A. 1985 - Another aquatic hyphomycete genus from foam. Transactions of the British Mycological Society 85(1), 174-177.

Nawawi A, Kuthubutheen AJ. 1988 - Additions to Condylospora (hyphomycetes) from Malaysia. Mycotaxon 33, 329-338.

Nemec S. 1970 - Fungi associatedwith strawberry root rot in Illinois. Mycopathologia et Mycologia applicata 41(3-4), 331-346.

Nilsson S. 1964 - Freshwater hyphomycetes. Taxonomy, morphology and ecology. Symbolae Botanicae Upsaliensis, Uppsala.

Pascoal C, Marvanová L, Cássio F. 2005 - Aquatic hyphomycete diversity in streams of Northwest Portugal. Fungal Diversity 19, 109-128.

Paulus BC, Kanowski J, Gadek PA, Hyde KD. 2006 - Diversity and distribution of saprobic microfungi in leaf litter of an Australian tropical rainforest. Mycological Research 110, $1441-1454$.

Petersen H. 1963a - Aquatic hyphomycetes from North America: III. Phialosporae and miscellaneous species. Mycologia 55(5), 570-581.

Petersen H. 1963b - Aquatic hyphomycetes from North America. II. Aleuriosporae (Part 2), and Blastosporae. Mycologia 55(1), 18-29.

Plakidas AG, Edgerton CW. 1936 - A new imperfect fungi. Mycologia 28, 82-84.

Ranzoni FV. 1953 - The aquatic hyphomycetes of California. Farlowia 4, 353-398.

Roldán A, Descals E, Horunbia M. 1989 - Pure culture studies on Tetracladium. Mycological Research 93(4), 452-465.

Rosa CA, Rosa LH, Medeiros AO, Fonseca FG da. 2009 - Diversidade Microbiana. In: Biota Minas-Diagnóstico do Conhecimento sobre a Biodiversidade no Estado de Minas Gerais. 
(eds Drummond GM, Martins CS, Greco MB, Vieira F.). Biodiversitas, Belo Horizonte 4365.

Santos-Flores C, Betancourt-López C. 1994 - Aquatic hyphomycetes (Deuteromycotina) from Rio Loco at Susua State Forest, Puerto Rico. Caribbean Journal of Science 30(3-4), 262-267.

Santos-Flores CJ, Betancourt-López C. 1997 - Aquatic and water-borne hyphomycetes (Deuteromycotina) in streams of Puerto Rico (including records from other Neotropical locations). College of Arts and Sciences, University of Puerto Rico, Mayaguez.

Santos-Flores CJ, Betancourt-López C, Nieves-Rivera AM. 1996a - New records of water-borne hyphomycetes for Puerto Rico. Caribbean Journal of Science 32(1), 105-110.

Santos-Flores CJ, Nieves-Rivera AM, Betancourt-López C. 1996b - The genus Condylospora Nawawi (Hyphomycetes) in Puerto Rico. Caribbean Journal of Science 32(1), 116-120.

Sati SC, Tiwari N, Belwal M. 2002 - Conidial aquatic fungi of Nainital, Kumaun Himalaya, India. Mycotaxon 81, 445-455.

Sati SC, Arya P, Belwal M. 2009 - Tetracladium nainitalense sp. nov. a root endophyte from Kumaun Himalaya, India. Mycologia 101(5), 692-695.

Schoenlein-Crusius IH. 2002 - Aquatic hyphomycetes from cerrado regions in the state of São Paulo, Brazil. Mycotaxon 82, 457-462.

Schoenlein-Crusius IH, Grandi RAP. 2003 - The Diversity of Aquatic Hyphomycetes in South America. Brazilian Journal of Microbiology 34,183-103.

Schoenlein-Crusius IH, Malosso E. 2007 - Diversity of aquatic hyphomycetes in the tropics. In: Fungi: Multifaceted microbes. (eds Ganguli BN, Desmukh SK.). Anamaya Publishers, Nova Delhi 61-81.

Schoenlein-Crusius IH, Milanez AI. 1989 - Sucessão fúngica de folhas de Ficus microcarpa L. F. submerged no lago frontal situado no Parque Estadual das Fontes do Ipiranga, São Paulo, SP. Revista de Microbiologia 20(1), 95-101.

Schoenlein-Crusius IH, Milanez AI. 1990 - Hyphomycetes aquáticos no Estado de São Paulo, Brasil. Revista Brasileira de Botânica 13, 61- 68.

Schoenlein-Crusius IH, Milanez AI. 1998 - Fungal succession on leaves of Alchornea triplinervia (Spreng.) Muell. Arg. submerged in a stream of an Atlantic Rainforest in the state of São Paulo, Brazil. Revista Brasileira de Botânica 21(3), 253-259.

Schoenlein-Crusius IH, Pires-Zottarelli CLA, Milanez AI. 1990 - Sucessão fúngica em folhas de Quercus robur L. (carvalho) submersas em um lago situado no município de Itapecerica da Serra, SP. Revista de Microbiologia 21(1), 61- 67.

Schoenlein-Crusius IH, Pires-Zottarelli CLA \& Milanez AI. 1992 - Aquatic fungi in leaves submerged in a stream in the atlantic rainforest. Revista de Microbiologia 23(3), 167-171.

Schoenlein-Crusius IH, Moreira CG, Bicudo DC. 2009 - Aquatic hyphomycetes in the Parque Estadual das Fontes do Ipiranga - PEFI, São Paulo, Brazil. Revista Brasileira de Botânica 32(3), 411-426.

Silva RF, Briedis GS. 2009 - Registro de la presencia de hifomicetos acuáticos en rios de la cordillera de la costa, Venezuela. Interciencia 34(8), 589-592.

Silva RF, Briedis GS. 2011 - Hifomicetos acuáticos de la cabecera de rio Guaríco. Estado Carabobo, Venezuela. Interciencia. 36(11), 831-834.

Sinclair HI, Morgan-Jones G. 1979 - Notes on hyphomycetes. 32. Five new aquatic species. Mycotaxon 9(2), 469-481.

Singh N, Musa TM. 1977 - Terrestrial occurrence and the effect of temperature on growth, sporulation and spore germination, of some tropical aquatic hyphomycetes. Transactions of the British Mycological Society 68(1), 103-106.

Smits G, Fernández R, Cressa C. 2007 - Preliminary study of aquatic hyphomycetes from Venezuelan streams. Acta Botánica Venezuelica 30(2), 345-355.

Sridhar KR, Karamchand KS. 2010 - Diversity of water-borne fungi in stemflow and throughfall of tree canopies in India. Sydowia 61, 327-344. 
Tubaki K. 1965 - Short note on aquatic spora in East New Guinea. Transactions of the Mycological Society of Japan 6, 11-16.

Webster J. 1977 - Seasonal observations on aquatic hyphomycetes on oak leaves on the ground. Transactions of the British Mycological Society 68(1), 108-111.

Yen LTH, Inaba S, Tsurumi Y, Ban S, Lan Dung N, Van Hop D, Ando K. 2012 - Condylospora vietnamensis, a new ingoldian hyphomycete isolated from fallen leaves in Vietnam. Mycoscience 53, 326-329. 